\title{
Refurbishment Projects
}




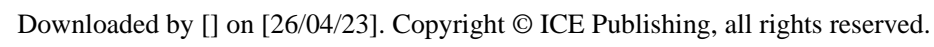




\section{Refurbishment Projects}

Health and safety management

\section{Edited by Dr David Oloke}

BEng MSc PhD PGCert HE FHEA CEng MICE MCIOB MNSE

University of Wolverhampton 
Published by ICE Publishing, One Great George Street, Westminster, London SW1P 3AA.

Full details of ICE Publishing representatives and distributors can be found at: www.icebookshop.com/bookshop_contact.asp

\section{Other titles by ICE Publishing:}

ICE Manual of Health and Safety in Construction, Second edition. Ciaran McAleenan and David Oloke (eds). ISBN 978-0-7277-6010-4 Health and Safety: Questions and answers, Second edition.

Pat Perry. ISBN 978-0-7277-6074-6

Progressive Collapse of Structures, Second edition.

Uwe Starossek. ISBN 978-0-7277-6168-2

www.icebookshop.com

A catalogue record for this book is available from the British Library

ISBN 978-0-7277-6159-0

(C) Thomas Telford Limited 2020

ICE Publishing is a division of Thomas Telford Ltd, a wholly-owned subsidiary of the Institution of Civil Engineers (ICE).

All rights, including translation, reserved. Except as permitted by the Copyright, Designs and Patents Act 1988, no part of this publication may be reproduced, stored in a retrieval system or transmitted in any form or by any means, electronic, mechanical, photocopying or otherwise, without the prior written permission of the Publisher, ICE Publishing, One Great George Street, Westminster, London SW1P 3AA.

This book is published on the understanding that the author is solely responsible for the statements made and opinions expressed in it and that its publication does not necessarily imply that such statements and/or opinions are or reflect the views or opinions of the publishers. While every effort has been made to ensure that the statements made and the opinions expressed in this publication provide a safe and accurate guide, no liability or responsibility can be accepted in this respect by the author or publishers.

While every reasonable effort has been undertaken by the author and the publisher to acknowledge copyright on material reproduced, if there has been an oversight please contact the publisher and we will endeavour to correct this upon a reprint.

Cover photo: Collage of colourful windows with pediment of Prague, Czech Republic. Delpixart/iStock

Commissioning Editor: James Hobbs

Development Editor: Melanie Bell

Production Editor: Madhubanti Bhattacharyya

Marketing Specialist: April Nagy

Typeset by The Manila Typesetting Company

Index created by Pierke Bosschieter

Printed and bound in Great Britain by Henry Ling, Dorset 
01

\section{Introduction}

1.1. Introduction

1.2. Overview

1.3. Background

1.4. The scope of this book

1.5. Definitions of key words

1.6. Conclusion

Bibliography
$02 \ldots \ldots \ldots \ldots \ldots \ldots \ldots \ldots \ldots \ldots$ Managing alteration and refurbishment projects

2.1. Introduction

2.2. Procurement matters

2.3. Key health and safety duty holders in refurbishment projects

2.4. Managing information and communication

2.5. Information and communication life cycle

2.6. Conclusion

20

Bibliography

03

Technical issues on alteration and refurbishment projects

3.1. Introduction

3.2. Technical information

3.3. Loadings and load paths

3.4. Surveys

3.5. Structural testing

3.6. Case studies - using the project cycle approach to technical issues

3.7. Discussion and proposed framework

3.8. Conclusion

Bibliography

04

\section{Building adaptation principles}

4.1. Introduction

4.2. Modern challenges and their significance in terms of legislation

4.3. Adaptation procedure

4.4. Adaptation techniques

4.5. Conclusion

Bibliography 
5.1. Introduction 67

5.2. What do EEPs constitute?

5.3. Why are extension and expansion projects normally undertaken?

5.4. Client development motivations 69

5.5. VAT on extension projects 72

5.6. Linear/horizontal and vertical extensions 72

5.7. What is operation analysis and control (OAC)? 73

5.8. What specific hazards are associated with EEPs? 78

5.9. Conclusion 80

Bibliography $\quad 80$

06

\section{Loft conversions to domestic dwellings}

81

6.1. Introduction 81

6.2. Impact of different types of loft conversion on safety and health 81

6.3. Prevention 82

6.4. Management 83

6.5. Tools, equipment and personal protection

6.6. Commonly found hazards 85

6.7. Conclusion 92

Bibliography $\quad 92$

$07 \ldots \ldots \ldots \ldots \ldots \ldots \ldots \ldots \ldots \ldots \ldots \ldots$ Basement construction, extension and alteration projects $\quad 95$

7.1. Introduction 95

7.2. Significant issues in basement refurbishment 95

7.3. Case study of a basement alteration project 96

7.4. Construction work methods 98

7.5. Pre-construction health and safety information
for a typical basement alteration

7.6. Conclusion 107

Bibliography 107

$08 \ldots \ldots \ldots \ldots \ldots \ldots \ldots \ldots \ldots$ Innovation in alteration and refurbishment

project delivery 109

8.1. Introduction 109

8.2. Background 109

8.3. Refurbishment with BIM 110

8.4. Data capture techniques 111

8.5. Future directions 114

8.6. Conclusion 116

$\begin{array}{ll}\text { Bibliography } & 117\end{array}$ 
9.1. Introduction

9.2. Case study 1 - Design risk assessment

9.3. Case study 2 - Managing asbestos materials

9.4. Case study 3 - Client commissions a small construction project with a hands-on approach

9.5. Case study 4 - Mobile elevating work platform used in façade repairs

9.6. Case study 5 - Collapse of office building kills four workers

9.7. Conclusion

Bibliography

10

\section{Sustainable practices in the project life cycle}

10.1. Introduction

10.2. Sustainability as a traditional state-of-the-art strategy 140

10.3. The construction and real estate industry as a sustainability key factor

10.4. Certified build sustainability

10.5. Specialised certification tools for refurbishment projects

10.6. Future tasks for sustainable health and safety management

10.7. Conclusion

Bibliography

Index 


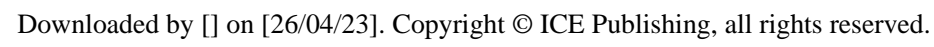




\section{About the editor}

David Oloke is a chartered civil engineer and construction manager with over 30 years of international professional experience. Throughout this period, David has been working mostly as a consulting engineer, project manager, researcher and academic practitioner. He has also served as a planning supervisor, construction design and management coordinator, and principal designer and designer on several projects in the UK. To date, he has been responsible for projects worth a total of over $£ 150$ million. David has been a member of the ICE Health and Safety Expert Community for over 15 years, serving as the chair of the ICE Health and Safety Register Working Group between 2012 and 2017. He was also co-editor on the ICE Manual of Health and Safety in Construction published in 2010 and 2015. In addition, David is co-chair for the annual RefurBIM conference, which brings together industry and academia to discuss the challenges and opportunities of implementing building information modelling (BIM) in renovation and refurbishment. 


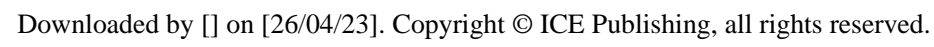




\section{About the contributors}

Louis Gyoh, a chartered architect and BIM manager, has worked in the architecture, engineering and construction (AEC) sector for 20 years. He rejoined the higher education sector in 2010. Louis's research interests are design risk management and design for deconstruction in BIM-led projects. Louis has consulted extensively for the World Bank Group, German Corporation for International Cooperation (GIZ), Cheveron and USAID. He is currently a principal lecturer at the School of Architecture and the Built Environment, Faculty of Science and Engineering, University of Wolverhampton, UK.

Anthony Hatfield has over 25 years' experience in the building surveying profession, and is currently a senior lecturer in building surveying at the University of Wolverhampton, UK. He has managed and worked on numerous projects, including new build residential and commercial units, brownfield regeneration schemes, and the conversion and adaptation of the existing built environment. He was at the vanguard of drone technology being introduced into the building surveying curriculum. Anthony is a chartered construction manager and obtained an MSc with distinction in conservation of the historic environment.

David Heesom is currently a reader in BIM at the University of Wolverhampton, UK. He has spent 20 years researching the application of advanced digital technologies for architectural design and construction, publishing his work in international journals and speaking at events around the world, including the USA, China and throughout Europe. David is co-chair for the annual RefurBIM conference, which brings together industry and academia to discuss the challenges and opportunities of implementing BIM in renovation and refurbishment. David has won numerous funded research awards, and works closely with companies around the UK to support them in implementing BIM and digital technologies to enhance their processes.

Ciaran McAleenan has worked in industry since 1978, and joined the faculty at Ulster University in 2009. His particular research interests led to the co-creation of the Civic Ecology and Life Infrastructure group (CELI). Projects under this group address the impacts of infrastructure designs that expose the world to or are failing to protect the world from future hazards (natural and/or technological), and which raise environmental concerns that need to be tackled in life infrastructure designs. Ciaran focuses on the societal challenges presented by the United Nations Sustainable Development Goals and how engineering education needs to evolve to address the challenges of the 21 st century, in particular the climate emergency.

Philip McAleenan is an independent researcher and consultant at Expert Ease International, a company he co-founded in 1996 to address the health, safety and wellbeing requirements of organisations. Innovatory work on the reintegration of occupational safety and health 
into work practices and research into workplace cultural maturity has led Philip to develop new perspectives on leadership and ethics reasoning in the workplace. His current research is into the social and ethical impacts of the application of artificial intelligence systems on worker agency and safety.

Carmen Mielecke is a founder and CEO of Life Cycle Engineering Experts (LCEE), a consultancy company specialising in the sustainable built environment. At LCEE she deals with the sustainability of building materials, construction and the real estate industry. In particular she advises customers of the construction and real estate industry on national and international sustainability certification. Carmen is a LEED advanced professional, a BREEAM assessor and auditor, a DGNB (German Sustainable Building Council) senior auditor and a building biologist. In addition, she is lecturer for sustainable building and construction at Darmstadt Technical University, Germany. After studying architecture she worked as an architect, and then moved to Darmstadt Technical University where she gained her $\mathrm{PhD}$ in 2011.

Torsten Mielecke is a founder and CEO of Life Cycle Engineering Experts (LCEE), a consultancy company specialising in the sustainable built environment. At LCEE he deals with the sustainability of building materials, construction and the real estate industry. In particular he advises customers of the construction and real estate industry on national and international sustainability certification. In addition, he is lecturer for sustainable building and construction at Darmstadt Technical University, the University of Applied Sciences in Münster and the University of Applied Sciences in Wiesbaden, Germany. After studying mechanical and industrial engineering he moved to Darmstadt Technical University, where he finished his $\mathrm{PhD}$ in 2013.

Pat Perry MCIEH MIOSH qualified as an environmental health officer in 1978, and spent the early years of her career in local government enforcing environmental health regulations, particularly health and safety law. Pat set up her own environmental health consultancy, Perry Scott Nash Associates Ltd (PSN), in 1988. In 2013 the consultancy joined a global group on regulatory compliance and safety management. Pat developed an expertise in the Construction (Design and Management) Regulations 1995, advising clients on their legal duties and undertaking the roles of planning supervisor and subsequently CDM coordinator under the 2007 Regulations. Pat wrote her first book on the 1995 CDM Regulations for Thomas Telford and then wrote on the 2007 CDM Regulations for Butterworth Heinemann. Pat's most recent books have been published by ICE, and include a series of questions and answers, including those on CDM 2015, risk assessment and health and safety. Pat continues to advise clients on the CDM 2015 and general health and safety, and has wide experience of refurbishment projects, particularly in the retail and hospitality sectors. 
Sebastian Pohl has been a member of the managing board and a partner at Life Cycle Engineering Experts (LCEE), a consultancy company specialising in the sustainable built environment, since 2015. At LCEE he deals with the sustainability of building materials, construction and real estate industry. In particular he advises customers of the construction and real estate industry on national and international sustainability certification. In addition, he is lecturer for sustainable building and construction at Darmstadt Technical University and the University of Applied Sciences in Münster, Germany. After studying business and civil engineering, in 2010 he began working for a major management consultancy. He then moved to Darmstadt Technical University, where he finished his $\mathrm{PhD}$ in 2014.

Robert Weatherup lectures in construction economics with specialisms in whole-life value engineering and disaster response and recovery. $\mathrm{He}$ is the co-founder of the research group CELI (Civic Ecology and Life Infrastructure), which investigates the global societal challenges of health, food security, ecosystem biodiversity and smart green integrated communities. His research interests involve thinking differently about how we design, construct and use our built environment, specifically investigating engineering nature-based solutions to enhance biodiversity and the economics of procuring and managing biodiversity ecosystem services. 